\title{
MEANINGS REGARDING THE USE OF ALCOHOL IN FAMILIES OF A VENEZUELAN POOR COMMUNITY
}

\author{
Carlos Onorio Castillo ${ }^{1}$ \\ Maria Cristina Silva Costa ${ }^{2}$
}

Onorio Castillo C, Costa MCS. Meanings regarding the use of alcohol in families of a Venezuelan poor community. Rev Latino-am Enfermagem 2008 maio-junho; 16(especial):535-42.

This study is the result of an ethnographic research based on interpretative anthropology. It aims to interpret the meanings of alcohol misuse in families from a poor Venezuelan community. Twenty members from six families participated in the study. The results show differences between meanings children and parents held regarding alcohol consumption. Children held a more positive view, whereas mothers presented the lowest acceptation of alcohol consumption. Meanings were more convergent than divergent, which allowed the identification of the following units: excessive consumption, intoxication, and joy. The association of alcohol with parties and joy is the main motivation to drink and the main barrier to change drinking habits. Two units of meaning were identified: a continuum between normal and pathologic drinking; and concept of joy subordinated to alcohol consumption.

DESCRIPTORS: alcoholism; family; public health; anthropology, cultural; nursing

\section{SIGNIFICADOS DEL CONSUMO DE ALCOHOL EN FAMILIAS DE UNA COMUNIDAD POBRE VENEZOLANA}

Resultado de investigación etnográfica basada en la antropología interpretativa, este trabajo objetiva interpretar los significados del consumo de alcohol en familias de una comunidad pobre venezolana. Han sido investigadas seis familias, totalizando 20 participantes. Los resultados indican algunas distinciones entre padres, madres e hijos en la atribución de significados al consumo de alcohol, con una visión más valorativa en los hijos y menor aceptación entre las madres. Las convergencias de sentidos, más frecuentes que las diferencias, permitieron identificar las unidades de significación: el consumo excesivo, la borrachera, la alegría. En la asociación entre bebidas alcohólicas, alegría y fiesta está la principal motivación para beber y la principal fuente de resistencia a la modificación de conductas ante el alcohol. Los núcleos de significados identificados fueron: la existencia de un continuo entre el beber normal y patológico; una concepción de felicidad subordinada al consumo del alcohol.

DESCRIPTORES: alcoholismo; familia; salud pública; antropología cultural; enfermería

\section{SIGNIFICADOS DO CONSUMO DE ÁLCOOL EM FAMÍLIAS DE UMA COMUNIDADE POBRE VENEZUELANA}

Resultado de pesquisa etnográfica, sob a ótica da antropologia interpretativa. Este trabalho objetiva interpretar significados do consumo de álcool em famílias de uma comunidade pobre venezuelana. Seis famílias foram pesquisadas, totalizando 20 participantes. Os resultados mostram diferenças entre pais, mães, e filhos, na atribuição dada aos significados do consumo de álcool, tendo uma visão mais valorativa dos filhos, e menor aceitação entre as mães. As convergências de sentidos foram mais freqüentes que as diferenças, permitindo identificar as unidades de significado: consumo excessivo, bebedeira e alegria. Na associação das bebidas alcoólicas com alegria e festa encontra-se a principal motivação para beber, e a principal fonte de resistência para a modificação de condutas perante o álcool. Os núcleos de significados identificados foram: existência de um contínuo entre o beber normal e o patológico, sendo uma concepção de felicidade perante o consumo de álcool.

DESCRITORES: alcoolismo; família; saúde pública; etnografia; enfermagem

${ }^{1}$ M.Sc. in Nursing, Professor, University of Carabobo, School of Health Sciences, School of Nursing Dr. Gladys Román de Cisneros, Venezuela; ${ }^{2}$ PhD in Social Anthropology, Professor, University of São Paulo at Ribeirão Preto, College of Nursing, WHO Collaborating Centre for Nursing Research Development, Brazil, e-mail: mccosta@eerp.usp.br 


\section{INTRODUCTION}

Over the last decades, no country remained unaffected by the serious problems caused by the improper use of drugs, among them, alcohol. In various countries, the alcohol-consuming population has increased and consumption is starting at a younger age. In the United States, at least 9 million adults are subject to the alcohol problem ${ }^{(1)}$. In Venezuela, there are 5.722.000 alcoholics, which implies a rate of more than 30/1000, and a consumption rate of about 13 liters of alcohol per year per person older than $15^{(2)}$.

Since the mid 19th century, alcoholism has been considered a disease and has become an object of medical studies ${ }^{(3)}$. In 1995 , the World Health Organization recognized that this disease had to do with psychological problems: "Alcoholics are people who drink excessively and whose dependence with regard to alcohol has reached a certain degree that determines the appearance of visible mental disorders, or a certain influence on their physical and mental health, interpersonal relationships, and in the adequate social and economical operations"(4).

The psychological components of the disease were recognized by the World Assembly of Health in 1976, in its definition of the alcohol dependence syndrome: "A psychological and, usually, also physical condition, resulting from alcohol consumption, characterized by a behavior and another responses that always include the compulsion for consuming alcohol in a continuous or periodic fashion, with the goal to experience psychological effects and, sometimes, avoid the harms produced by its absence, with or without tolerance ${ }^{\prime \prime(5)}$. Despite being a physical and psychological disease, the first social studies on the theme date back to the $1960 s^{(6)}$.

Epidemic studies reveal that alcohol is the most consumed drug in young people, who start consumption as a kind of initiation ritual to adolescence: in their socialization, they associate alcoholic beverages as indispensable at any party. It is observed that this association between fun and alcohol is a global phenomenon, and that $5 \%$ of deaths of individuals between 15 and 19 years of age, worldwide, are associated with alcohol consumption ${ }^{(7)}$. Therefore, alcoholism is a problem with medical, psychological, educational and sociocultural implications.

The consumption of alcoholic beverages causes $4 \%$ of all diseases and is also associated with about $20 \%$ to $40 \%$ of cases of esophagus cancer, hepatitis, epilepsy, aggressions and homicides ${ }^{(7)}$. This not only affects collective health, but also worsens the living conditions of poor communities ${ }^{(8)}$.

In Venezuela, alcoholism is a serious public health issue, especially concerning communities living on the outskirts of cities, where delinquency and extreme poverty are observed. The National Institute of Statistics has reported that, in 2006, the rates of "extreme poverty" reached $13.3 \%$ of the Venezuelan population, considering families who consume less than one food basket (a value between Bs. 500,000 and 650,000$)^{(8)}$. On the average, Venezuelan families living in the peripheries receive less than two minimum wages, which means that they cannot buy the food basket. These families constitute the most vulnerable group to drugs in Venezuela, with consumption starting at a very early age (10 to 19 years), and generally with alcohol.

In this population, there has been an increase in the use of psychotropic and other drugs, and alcohol is the most consumed substance. The association between alcohol consumption and traumas or lesions by external causes, recognized by international institutions (in Americas, $43.9 \%$ of traumas and $28.1 \%$ of lesions occur among individuals who reported recent alcohol consumption ${ }^{(9)}$ ), is worse in poor communities. In the studied community, seven out of every ten crimes or law offences are committed under the effects of drugs or with the goal of obtaining the money to buy them ${ }^{(10)}$.

Despite the large amount of information around the issue, few studies address the values and motivations associated with alcoholism, considering the social and cultural context. This lack justifies a focus on alcoholism as an expression of a symbolic reality, concerning concrete subjects and family problems in marginal communities. This motivated the present study, with the goal of interpreting the meanings of alcohol consumption in families from a peripheral community.

\section{METHODOLOGY}

The research that originated this article was developed in Venezuela in 2007, and complied with the ethical procedures for research involving human beings. Approval was obtained from the Ethics Committee at the University of Carabobo College of Nursing. The participants provided written consent and had their identities preserved. 
The inclusion criteria for subjects were: family members living in Brisas de Carabobo, a peripheral community of the municipal district Naguanagua; adults between 20 and 60 years old, of both genders, alcohol consumers or not, with access to the health facilities that cover the area of the community and who agreed to take part in the research. Six out of ten randomly selected families met all the criteria, constituting a group of twenty subjects (six fathers, six mothers and eight children).

The method used to interpret the meanings of alcohol consumption in the families was ethnography, understood as a "dense description"(11) that searches for meanings. The study was performed from the perspective of interpretative anthropology which, based on the theoretical paradigm of hermeneutics ${ }^{(12)}$, aims to interpret the meanings of practices, motivations, conceptions, integrating them in the cultural context.

The main techniques used to apprehend the cultural logic in which the conducts and conceptions regarding alcohol obtain meanings in the community were participant observation and in-depth interviews. The interviews were recorded and literally transcribed. They were conducted as dialogs between the researcher and the family members, considering each participant's different perspectives ${ }^{(13)}$. Observation involved the researcher's participation in the subjects' various life situations: family routine, parties, recreation, meeting with friends. This way, it was possible to apprehend the conducts and to look beyond the excuses presented in the reports.

Data analysis demanded exhaustive readings of the interview transcriptions and observation notes, looking for similarities and differences in the subjects' actions and conceptions. In addition, the data was organized in units of meaning. Cores of meaning were elaborated and contextualized according to the hermeneutical interpretation ${ }^{(12-13)}$.

\section{RESULTS}

Mist of Carabobo: life in the community

The community Mist of Carabobo, on the outskirts of Naguanagua, a city located within the geographical area of Valencia, the state capital of Carabobo, was founded in 1983 and, according to information from the people's council, has a population of approximately 5,400 inhabitants. Adults work in informal trade or temporary service institutions. Some men work as bricklayers, salespersons or collectors; most women receive governmental help through social programs.

Most houses are built in blocks, with some expansion in their construction. Electric power and water supplies are available only some days per week. There is a health outpatient clinic and a popular clinic in the community. Besides the illicit bars in family homes, the community has two licensed liquor stores, whose owners report selling approximately 50 boxes of alcoholic drinks.

It is observed that, in the community, it is common for people, adults and teenagers, to spend time in liquor stores, especially after work, around five in the afternoon. There, they spend hours consuming alcoholic beverages, especially beer, until dawn and making a lot of noise. Some of these encounters occur during the week, but they happen mainly at weekends, or in the case of a special celebration.

The observations and interviews revealed that the families use the party meetings or reunion with friends as a reason to share alcohol. In parties, it is observed that family members give small children beer or any other kind of alcoholic beverage, which they celebrate with laughter, applauses and sentences like: That is for them to learn very young, and not be fooled when they grow up!

Alcohol consumption in families from the community

Data analysis revealed similarities and divergences among the study subjects. In all families, one or more members consume alcoholic beverages. Two of these families consume sporadically (during parties or travels) and four habitually, mainly at weekends. One of the families consumes alcohol beverages on a daily basis. A common characteristic, therefore, is the occasional or frequent consumption of alcoholic beverages by at least one family member.

The main particularity observed was greater acceptance of consumption among the youth; a situation mothers consider unacceptable. Convergent meanings were more significant than differences. Those convergences allowed for the identification of three units of meaning: excessive consumption, drunkenness and happiness. 
Excessive consumption

The habitual consumption of alcoholic beverages was observed in the community and reported by the interviewees, defined by many as excessive and verified particularly among the youth: among those living around here, consumption is quite high [...], in the youth it is excessive, because they sometimes like parties, and, with parties come the drinks [...]. For example, the youth look forward to the weekends because of the parties. Alcohol, of course, is bad for them in the beginning but, over time, they make a habit out of it. They obtain credit at the restaurant so they can have more money to consume beer, which is the most consumed beverage around here (father).

Most of the youths that took part in this research reported habitual consumption of alcoholic beverages, and some also admit the misuse of other drugs. Many of them recognize their consumption as excessive: in my opinion, it's relaxing. I feel good when I drink, it makes me feel well and cheerful. Sometimes, when I came home stressed from work, I had some alcohol. Now, I'm quitting, because I know that it isn't good. I've been so addicted to alcohol that I stopped buying my things to go to parties and drink. I've not drunk any alcohol for a month and a half now (son).

According to the subjects, there are no gender differences in terms of alcohol misuse: We drink alike, I know men who drink very slowly, while they drink like, I drink quite a lot of beer. While he drinks one I drink three... it's not the same. I ask you if women can consume less? I answer myself that no, sometimes women consume much more than men. At least in the group I know women have an advantage in this sense (father). Nevertheless, consumption levels are higher and more frequent among adult men (fathers) and among youth of both genders, when compared to the studied mothers.

Although consumption levels of alcoholic beverages are higher during parties, many of the subjects report daily drinking at home: Well, I can't talk much about parties... because at parties I don't know ... I drink more at home. My husband buys beer to avoid that I go out to drink (mother). A father stated he drinks every day of the year.

The drinking spree

In the interviews, all subjects recognize the negative effects alcohol has on their organism: well, the indisposition after being drunk isn't pleasant, it's awful. We got tremors, headaches. But we see that, soon it's gone. Also, to cure this indisposition, we drink another beer (father). Another subject highlights: the drinking spree, the vomit, the happiness. A mother reports: my brother-in-law became sick; he has liver problems due to drinking. A father affirms that he no longer drinks, and says: I didn't drink yesterday, I don't miss it. But I've got many friends [...] one of them died of liver cirrhosis. Another one had to amputate a leg. I have many friends with problems, economic problems. And I know many women who drink a lot. A young man describes the effects alcohol has on the organism: it causes nausea, dizziness, balance loss while walking, everything rotates when we lay down, heartburn, a lot of thirst, a need to urinate all the time, and it harms the liver.

The interviews also highlight the effects on the mind and the changes in their conduct: we get happy but, actually, we feel scared. Some have one personality without alcohol but, when they drink, they show an aggressive personality (father). A mother affirms: when my father drank, he was impertinent. On one occasion, he drank so much that he fainted. He drank every Saturday, drank "guarapita", put some lemon and sugar and drank. A mother describes: Some get annoying, others get happy, they feel more comfortable but, in fact, it isn't nice to drink with problematic people. In other words, what they call 'people who do not know how to drink', because they drink only five or six drinks and already look for a fight [...] Well, I only want to dance, that's all. And, if there is food, I eat; if not, I don't. Another mother emphasizes the compulsion towards progressive misuse: Well, at the beginning, I felt a tingling in the brain. In other words, the wish for beer. Because of that, we can't say 'I will drink three more", because it's a lie. After the third, comes the rest and we loose track.

The most highlighted conducts associated with alcohol misuse for young people are: to make mistakes, to stay with men in bed (daughter); be aggressive, be impetuous and to feel vivacity (son); feel like dancing (daughter). Some relate drinking with car accidents: causes accidents on the streets, because drunken people don't think (son). In general, the youths relate alcohol misuse with the violation of standard behavior: when we drink, we feel happier, less shy. I feel more capable to do things that I normally don't do (daughter). Another daughter says: what happened with a friend was that she went to bed with someone she had met the same night, go to bed with anyone.

Fathers and mothers deal with family problems caused by alcohol misuse: I saw many violent things, especially with my partner. We decided we both would stop drinking, because we got into fights every time we drank [...] (mother). A mother relates: my sister and my brotherin-law had a fight because they were drunk. I think that it wouldn't 
have happened if they had been sober. Another mother reveals: it was tough when my husband drank. Once, he brought a woman to help me in the house, because I was pregnant. When I came back from the hospital, after giving birth, I saw my husband holding her hand, helping her iron the clothes, grabbing her buttocks... Do you believe that... Well, I don't like scandals, so I told him to take that woman out of my sight.

In turn, children relate frequent family problems, caused by alcohol misuse: In the past, when I was a child and they could control my outings, they wouldn't let me drink. But now I'm older and I know how to take care of myself, I have to take care of myself, but they worry anyway. Before, my father was a drunk, but he got over it and he doesn't drink so much. But he used to drink on a daily basis (daughter). A young girl reports several problems: Well... It is a constant struggle with my mother, because she drinks a lot. I know that it damages the body, the liver, especially. But my mother drinks too much beer and we have some conflicts because of that. She transforms herself into an impertinent and unbearable person [...].

Many of the subjects related episodes of violence and accidents under the influence of alcohol: A friend of my daughter's, her classmate, has been in a vegetative coma for six years. She can't do anything by herself. She is still very ill. Everyone knows she is alive, because she still breathes. It was a car accident, and the driver was drunk (mother). Another mother showed her rejection of alcohol and other drugs, reporting the episode: A lot of people live next door. Everyone drinks the same amount. They begin at 6 a.m. and, by midnight, they end up going to the hospital, because they are stabbed, start fights, seem crazy. Another neighbor had a cat, poor animal. They soaked it in gasoline and set it on fire [...], this is sadism, it is a result of the drugs and the alcohol, because they sell white rum. It's always the same, they end up in a hospital, stabbed or arrested [...]. A father says: I've seen fights that resulted in victims with serious wounds. On one occasion, in a building, someone started a discussion and a drunk shot into the air, injuring a person that wasn't even involved.

Although most subjects are alcohol misusers, and another affirms its negative impacts, everyone reported cases of friends or family members who have or had problems due to consumption: In my family, we have an uncle who consumes alcohol excessively. We know that he is an alcoholic, we know that he has a disease, because the alcohol generates diseases. But nobody did anything for him (father). Look... Alcohol misuse is something that should not exist, because it destroys the family nucleus. It destroys yourself, destroys the family around you, destroys even your marriage [...] And I have the experience of my husband, who liked alcohol (mother).
The happiness

The main and biggest motivation for alcohol misuse, among parents and children, is associated with happiness and parties. The parents emphasize the relation between parties and beverages: When alcohol is present in the family, it is different, because everybody seems happier when drinking.

Among the youths, the search to feel well, relax and simply be happy and connect with other people stands out; the main motivation for drinking were: it makes me feel well and happy. A daughter states: drinking alcohol is partying, happiness, dancing and having a good time. In the youth's comprehension, drinking helps to: interact with friends, make friendships, celebrate birthdays, free themselves from stress, stay happy, recover from childhood traumas. Another participant emphasized: you feel happy, you feel well, it relaxes you to do different things but, at the same time, it leads you to dangers [...]. A son affirmed: almost everybody likes to drink, to feel well, to relax. Beer, whisky, rum, and there are people who even drink brandy.

The second most referred motivation is the influence of the family or peer groups, as one father emphasized: My friends said 'let's play, let's play soccer' but we never talked about going home so I stayed more and more, until midnight or one o'clock. A father who drank habitually mentioned drinking just for fun, not for addiction. I drink only on festival days or at family reunions. Before, I drank much more, now I almost don't drink. I usually drink beer, like now, but I prefer wine, because I'm taking care of my health. They say that wine has special properties, especially for the heart. Another man reports: drinking means gathering with friends in some place and drinking beer until we can't take it anymore. The quantity depends on each one [...].

The subjects frequently define the motivation to drink as just a desire, being conceived by many as a final good for family consumption, like any other product. Despite the restrictions to sell the product and the abusive prices, for example, now, we must go very early, because the prohibition doesn't allow us to drink 'til late. Besides, when this law is valid, the dealers increase the prices [...] (father). A mother reports: about selling the drinks, I think it is a little restricted, and we have seen many restrictions. Of course, I have a neighbor who sells. Sometimes I buy from him when I need to. We usually drink as a family, we don't like to go out. Another man reports: I know people who save part of their salaries for beer, just like for house expenses [...]. 


\section{DISCUSSION}

The meanings attributed to alcohol misuse, from the fathers', mothers' and children's viewpoints, indicate that it is not conceived as primordial; the abuse damages one's physical integrity, it is a vice, a disease, and there is excessive misuse among youths. Thus, it is considered a social problem. Contrarily, youths conceived drinking as something relaxing, and all subgroups associated it with distraction.

The subgroups also coincide in terms of the moment of misuse: weekends or party days and gathering with friends. There are, however, some (fathers and children) who admit drinking every day, and the youths associate misuse at weekends with their going to nightclubs.

Regarding the consequences of alcohol misuse, they express health and social problems: liver problems, general indisposition, headaches, nausea and vomiting, heartburn, accidents, family violence, fights and family difficulties. On the other hand, all subgroups emphasize that alcoholic beverages propitiate people's happiness.

The subjects' positive evaluation of alcohol misuse is related to occasional consumption, to entertainment and joy, although consumption is not restricted to these variables in many subjects. Fathers, mothers and children emphasize these associations as positive meanings attributed to beverages (in the reported situations) and as motivations for drinking. It was also noticed that young people who express greater acceptance emphasize drinking as something relaxing and as a way of social interaction. Contrarily, all of them reported social interaction difficulties due to excessive alcohol consumption.

Their motivations for alcohol misuse are based on positive evaluations: it allows gathering in groups or in family; it helps to feel free from stress, to be happy, interact, and celebrate special dates. On the other hand, negative evaluation is related to conducts associated withalcohol misuse: people drinking in the streets and bars, violence, accidents, economic problems, family problems, children buying beer for their parents; scandals and behaviors that extrapolate social rules.

The consumption of any alcoholic beverage represents something "normal" to the subjects, as long as limits are respected (a few glasses). It is observed that most families accept habitual consumption of alcoholic beverages, although all subjects reject excessive consumption - culminating with drunken people and leading to aggressive rulebreaking behavior.

In the studied cultural context, the meanings point at the core represented by a continuum between "normal" drinking, associated to health, and "abnormal" drinking, considered pathological. The amount ingested marks the distinction between fundrinking and disease-drinking. The disease, in that case, is understood as a biological fact, but also as a cultural fact, with symptoms that generate rulebreaking behaviors.

On the other hand, the consumption of alcoholic beverages, which is part of the families' lives, is only understood as a problem if excessive. Several studies express the importance of family life in maintaining or developing habits, including bad habits, or vices ${ }^{(1,3)}$. The families' behavior towards alcohol plays an important role in the socialization of its members and favors the development of vicious behaviors $^{(1)}$, since alcoholism is the last stage of a process that begins with occasional consumption, passing through moderate consumption, and which can cause excessive consumption ${ }^{(2)}$. Perhaps the excessive consumption identified among the youths reveals the influence of alcohol on the family.

Another important nucleus that structures the attribution of meanings is related with the association between the consumption of alcoholic beverages and happiness, celebration and friend reunion, which evidence social habits that are not exclusive of the studied community.

There are meanings associated with conceptions of "consuming happiness"(14) and dependents on hedonistic consumption, where the search for fruition and pleasure through drinking allows users to overcome everyday stress, anguish and weakness. In this sense, the subjects reported the conception of happiness identified in contemporary culture, characterized as "euphoric mythology, which walks side by side with the even greater misuse of euphoriants (alcohol and tranquillizers)"(14). The worldwide increased misuse of alcoholic beverages is a similar reality in the studied community, where misuse among youths is excessive and appears as a serious social problem ${ }^{(15)}$.

Government interventions were made in Venezuela, trying to reduce alcohol misuse through laws that increased taxes on national and imported alcoholic beverages (between 2006 and 2007) by30\%, 
and with the probability of a new raise in October 2007. This measure was taken through the "Law on taxes on alcohol and other alcoholic beverages"(16).

With the government's tax increase, the dealers raised alcohol prices and, thus, reduced their profit margin, especially for imported beverages. Despite these efforts, consumption remains the same in the community, as evidenced by the reports. The reduction in consumption levels was certainly not obtained through these general measures. An effective intervention must be oriented by logics directed at social groups that guide the social actor's conducts toward alcohol consumption.

\section{FINAL CONSIDERATIONS}

The study revealed important contradictions that can be explained through the positive and negative meanings attributed to the consumption of alcoholic beverages (joy and sociability), and those opposed to excessive misuse: the drinking spree, the addiction, the disease. The families recognize the negative influence, consequence of alcohol misuse, but they keep the behavior nonetheless.

Since alcohol consumption in the studied families was variable, orientation and support actions were necessary not only to solve physical, emotional and behavioral problems, but also to contribute to socialization. For this purpose, the health care team should bond with the families, encouraging them to create their own competence and to find their own solutions ${ }^{(17)}$. The importance of planning health actions in the context of alcohol misuse is unquestionable, as these actions could be efficient if guided by meanings built by the community itself.

Successful interventions in the studied community should be guided by the meanings socially attributed to alcoholic beverages. Therefore, the symbolic link between alcohol consumption, joy and happiness needs to be addressed (and untied). In its actions, the health care team could use the continuum identified between normal-drinking and pathologicaldrinking, highlighting another continuum observed in terms of alcohol-affected behavior, ranging from expressions of joy to dangerous and unruly behavior, which all participants in this research repudiate.

\section{ACKNOWLEDGEMENTS}

Acknowledgements to the Inter-American Drug Abuse Control Commission/CICAD of the SubSecretary of Multidimensional Security at the Organization of American States/OAS, the Brazilian Anti-Drugs Secretary/SENAD, faculty members at the University of São Paulo at Ribeirão Preto College of Nursing, WHO Collaborating Centre for Nursing Research Development, Brazil, to the population who participated in the studies and to the representatives from eight Latin-American countries who participated in the I and II On-Line Specialization Program for Research Capacity-Building on the Drugs Phenomenon-PREINVEST, offered in 2005/2006 by the University of São Paulo at Ribeirão Preto College of Nursing, as a distance education course.

\section{REFERENCES}

1. Berenson DMD. Family therapy. Alcohol and the family System. New York: Gardener Press; 1976.

2. López CM. Riesgos y beneficios del consumo de bebidas con alcohol: un enfoque de salud pública. En: Cuadernos FISAC (Fundación de Investigaciones Sociales), México $2000 ; 1(1): 56-78$.

3. Velasco FR. Las Adicciones: Manual para Maestros y Padres. México: Trillas; 1997.

4. Barr AD. A Social History of America. New York: Carroll and Graf Publishers; 1999.

5. Pittman DJ. Alcoholismo. Un enfoque interdisciplinario. Buenos Aires: Hormé; 1977.

6. Medina-Mora ME et al. Patrones de consumo de alcohol en México. En: Alcohol Consumption among Mexicans and MexicanAmericans: a binational perspective. California, University of California at Los Angeles (UCLA): Jean Gilbert; 1988.

7. Organización Mundial de la Salud (WHO/PSA/93.7); División de Salud Mental y Prevención del Abuso de sustancias). Ginebra, Suiza; 1993.

8. Fundación Centro Gumilla. La pobreza a debate. Caracas, Venezuela: Año LXIX (682) Marzo 2006: 52-5.

9. Organización Panamericana de la Salud. Las condiciones de salud para las Américas. Washington, D.C.: OPAS; 1998. 10. El fenómeno de las drogas. Caracas, Venezuela: Universidad Católica Andrés Bello (Ucab), Cátedra Libre Antidrogas (Cliad); 2007.

11. Geertz C. A Interpretação das Culturas. Rio de Janeiro: Zahar; 1978.

12. Geertz C. O Saber Local. Novos Ensaios de Antropologia Interpretativa. Petrópolis: Vozes; 1999.

13. Costa MCS. Intersubjetividade e historicidade: contribuições da moderna hermenêutica à pesquisa etnográfica. Rev Latino-am Enfermagem 2002 maio-junho; $10(3): 372-82$. 
14. Morin E. Cultura de Massas no Século XX: neurose. Rio de Janeiro: Forense Universitária;1997.

15. Gonzales C, Funes J, Gonzales S, Mayol I, Romani O. Repensar Las Drogas. Las Drogas Como Problema Social. Barcelona: Igia; 1988.

16. Decreto Oficial 5.618, de 3 de Octubre 2007. Venezuela: Gaceta Oficial No $5.852 ; 5$ de Octubre de 2007.

17. Waitzkin N. The Politics of Medical Encounters. How Patients and Doctors Deal With Social Problems. New Haven: Yale University Press; 1991. 